\title{
CHANGES IN THE ENERGY EFFICIENCY OF CROP PRODUCTION IN EU COUNTRIES
}

\begin{abstract}
Jindřich ŠPIČKA, Department of Strategy, Faculty of Business Administration, University of Economics, Prague, Nám. W. Churchilla 4, 13067 Praha 3. jindrich.spicka@vse.cz

The aim of the paper is to evaluate the change in the energy efficiency of crop production in the EU during the period 2002-2012. The energy efficiency is an important indicator of sustainability of agricultural processes. The energy-saving agriculture is a priority of the new Rural Development Programme in 2014-2020. Even though the analysis counts with main direct energy inputs into the crop production (fertilizers, fuels and pesticides), the methodology of the energy efficiency for commodities and farms uses all indirect nonrenewable energy inputs spent on production of buildings and machinery. The analysis covered 24 EU countries. The change in the energy efficiency in time was calculated through the Malmquist index. Clustering using medoids revealed groups of countries with similar energy efficiency. The Malmquist index identified the United Kingdom, Portugal and Sweden as countries with the most dynamic positive change in energy efficiency of the crop production in time. On the contrary, Baltic States and Poland experienced the most dynamic decline of energy efficiency. However, Lithuania, Latvia and Poland significantly increased the Malmquist index in recent years, partly as a consequence of effective investments from the Rural Development Programme (RDP). The energy efficiency indicator that includes direct and indirect energy inputs is supposed as suitable indicator for RDP's ex-post evaluation.
\end{abstract}

Keywords: Clustering, crop production, Malmquist index, sustainability.

\section{INTRODUCTION}

Increasing efficiency in energy use in agriculture is one of the Union priorities for rural development in 2014-2020, according to the Priority 5 of Rural Development Act (EU, 2013). Actions target at promotion of cost-effective investments of energy and using efficiency and cost-effective investment when constructing or renovating buildings. Moreover, actions have been carried out to promote the production and distribution of renewable energy sources.

The energy efficiency is more complex problem than the European Commission considers. Theoretical background of the energy efficiency provides Patterson (1996) - the energy efficiency is commonly defined by the ratio between outputs in physical units or converted to energy and inputs converted to energy. Energy efficiency is not only about direct energy inputs (fossil energy inputs, human power). Energy inputs should also include indirect energy inputs spent on production of materials (manufactured and organic fertilizers, seeds, pesticides) and long-term assets (buildings, machinery) used in agriculture. Agriculture plays the role of energy consumers and energy producers. It is unique system because it transforms solar energy into biomass that provides energy to ensure subsequent processes (e. g. it can be transformed to biofuels), or it can be used for food and feed production for human and animal nutrition. Agriculture should produce maximum energy output in crop and livestock production with minimum direct and indirect non-renewable energy input.

The energy efficiency can be calculated through parametric methods, e. g. Stochastic Frontier Analysis (Jelínek et al., 2010), or non-parametric methods of efficiency estimation, e. g. Data Envelopment Analysis (Hoang and Rao, 2010; Blancard and Martin, 2012; Curtiss and Jelínek, 2015). Non-parametric approach, applied in the paper, constructs a non-parametric frontier of efficient units which can be considered as benchmark for inefficient units (Nassiri and Singh, 2010, Houshyar et al., 2010).

Risoud (2000) emphasizes the energy efficiency as an important indicator of sustainability of agricultural processes. The issues are environmental, particularly for the control of greenhouse gas emissions and also for the evaluation of the use of scarce non-renewable resources. Socio-economic aspects consist in substitution of fossil energy by human labour. Curtiss and Jelínek (2015) revealed the great energy saving potential in conventional wheat production (ca. $50 \%$ ). The farm energy efficiency depends on farm- and technology-specific characteristics and farm specialization (crop versus livestock production). The significant positive impacts on energy efficiency have soil-conserving technology, timing of technological operations, water management and soil erosion. The energy efficiency enables to reveal the potential for energy saving at a farm level - fuel, fertilizers and other chemicals are the inputs with the significant potential for saving.

Copyright (C) 2015 The Authors. Published by Aleksandras Stulginskis University. This is an open-access article distributed under the terms of the Creative Commons Attribution License (CC-BY 4.0), which permits unrestricted use, distribution, and reproduction in any medium, provided the original author and source are credited. 
Energy efficiency can be calculated at a commodity level, micro-level (farms) and macro-level (regions and countries). At the micro-level, farms are aimed at cost minimization (or utility maximization) and energy saving (both is the result of price relations of inputs). At the macro-level, government should provide incentives to minimize negative impacts of production on the environment. Furthermore, government should concern about energy security which currently becomes more topical.

Literature has estimated the energy efficiency at a commodity-level (Kueters and Lammel, 1999; Jelínek et al., 2010; Celik et al., 2010; Uzal, 2013), farm-level (Risoud, 2000; Meul et al., 2007), regional level (Hu and Wang, 2006) and country-level (Vlontzos et al., 2014). Authors have also compared energy efficiency in organic farming (Risoud, 2000; Alonso and Guzman, 2010; Smith et al., 2015). Vlontzos et al. (2014) revealed that series of Eastern European countries achieved low efficiency scores before the EU accession due to low technology level being implemented in the primary production process. There were significant hints for considerable changes of energy and environmental efficiency after the implementation of the new CAP, with the new member states significantly differ of both energy and environmental efficiency compared with the older ones.

The aim of the paper is to evaluate the change in the energy efficiency of crop production in the EU. The evaluation of long-term change in energy efficiency in the period 2002-2012 should point to most successful countries as well as to identify countries which ought to target agricultural and energy policy more on efficiency issues. The paper obtains answers to three main questions.

1) Are there any clusters of countries with similar input-output energy relationship in the EU?

2) Which EU countries have experienced the most positive and negative change in the energy efficiency in the period 2002-2012?

3) Is it possible to identify the positive impacts of the "old" RDP on the improvement of the energy efficiency since 2007 ?

The paper is organized as follows. Data description is followed by the definition of energy efficiency, methods and inputs. Results describe output of the efficiency calculation and the cluster analysis. The final part of the paper contains the main findings and recommendations towards policy makers.

\section{METHODS AND DEFINITIONS}

The paper measures energy efficiency as multifactor productivity issue (MFP) which deals with the relationship between output and multiple input factors. The energy efficiency is defined as gross energy of useful products per nonrenewable energy inputs used to produce an output. The improvement of energy efficiency in agriculture was calculated through the Malmquist index. A producer can be defined as an economic agent transforming a set of inputs $\mathrm{x}=\left(\mathrm{x}_{1}, \mathrm{x}_{2}, \ldots, \mathrm{x}_{\mathrm{n}}\right)$ into a set of outputs $y=\left(y_{1}, y_{2}, \ldots, y_{m}\right)$. Generally, we consider the components of these vectors to be strictly positive. In order to define the Malmquist index of productivity (Caves et al., 1982), consider a period during which the production has changed from $\left(\mathrm{x}_{\mathrm{t}}, \mathrm{y}_{\mathrm{t}}\right)$ to $\left(\mathrm{x}_{\mathrm{t}+1}, \mathrm{y}_{\mathrm{t}+1}\right)$. A value of 1 signifies no change in efficiency, while values greater than 1 or less than 1 signify an increase or decrease, respectively. The Malmquist index is the product of two terms - a "frontier shift" term and a "catch-up" term. The catch-up (recovery) term relates to the degree to which a decision-making unit improves or worsens its efficiency with respect to the frontier in each period, while the frontier-shift (innovation) term reflects the change in the efficient frontiers between the two time periods (Cooper et al., 2006).

The input-oriented model assumes three inputs and one output per unit (country). The output and inputs need not to be deflated since the output is expressed in constant prices and inputs are measured in energy units (terajoules, TJ).

- $\quad$ Output (Faostat) = Gross production value, crop production (mil. USD, constant prices 2004-2006).

- Fertilizers $($ Faostat $)=$ nitrogen fertilizers $\left(\mathrm{N}\right.$, tonnes of nutrients), phosphate fertilizers $\left(\mathrm{P}_{2} \mathrm{O}_{5}\right.$, tonnes of nutrients), potash fertilizers $\left(\mathrm{K}_{2} \mathrm{O}\right.$, tonnes of nutrients), manure from all animals applied to soils $(\mathrm{kg})$. All fertilizers were put into one input through conversion coefficients $\left(\mathrm{N}=82.5 \mathrm{GJ} / \mathrm{t}\right.$ of nutrients, $\mathrm{P}_{2} \mathrm{O}_{5}=17.7 \mathrm{GJ} / \mathrm{t}$ of nutrients, $\mathrm{K}_{2} \mathrm{O}=9.6 \mathrm{GJ} / \mathrm{t}$ of nutrients, manure $=436 \mathrm{MJ} / \mathrm{t}$ ).

- Transport fuel used in agriculture, consumption in TJ (Eurostat) = gas/diesel oil (without bio components).

- Pesticides (Faostat, Eurostat) $=$ herbicides (tonnes of active ingredients) + fungicides \& bactericides (tonnes of active ingredients) + insecticides (tonnes of active ingredients). All pesticides were put into one input through conversion coefficients (herbicides $=340 \mathrm{GJ} / \mathrm{t}$ of active ingredients, fungicides $\&$ bactericides $=190 \mathrm{GJ} / \mathrm{t}$ of active ingredients, insecticides $=250 \mathrm{GJ} / \mathrm{t}$ of active ingredients).

Of course, electricity, water, machinery and human work should also be considered as energy inputs. Electricity is not significant input in crop production - it is more important energy source in animal production (pigs, poultry, dairy cows). The analysis of the energy efficiency focuses on non-renewable energy. Human power has been assumed as renewable energy. The reliable data about water consumption in agriculture, age and power of machinery are not available in datasets. The problem with unreliable data of water consumption emerges because agriculture consumes rainwater and not all farmers get water from public water mains (they have water well). Such water sources are difficult to exactly measure. The age and machinery power has been not surveyed by many statistical offices. So, the problem is systemic.

The energy efficiency approach assumes that agricultural output is expressed in energy units. Since we do not observe an accurate structure of the crop production in each country, we measure the crop output in value of production under the constant prices.

The cluster analysis attempts to show the different structures and the income level in agriculture within the EU. The medoid partitioning algorithms used here attempt to accomplish this by finding a set of representative objects called medoids. The medoid of a cluster is defined as that object for which the average dissimilarity to all other objects in the 
cluster is minimal. The medoid algorithm by Kaufman and Rousseeuw (1990) is applied. Two of the most difficult tasks in cluster analysis are deciding on the appropriate number of clusters and deciding how to tell a bad cluster from a good one. Kaufman and Rousseeuw define a set of values called silhouettes $(s)$ that provide key information about both of these tasks. The silhouette measures how well an object has been classified by comparing its dissimilarity within its cluster to its dissimilarity with its nearest neighbour. When $s$ is close to 1 , the object is well classified. When $s$ is near 0 , the object was just between clusters $\mathrm{A}$ and $\mathrm{B}$. When $s$ is close to negative one, the object is poorly classified. Kaufman and Rousseeuw interpret the average silhouette SC. When SC exceeds 0.5 , a reasonable structure has been found. Otherwise the structure is weak and could be artificial. The Manhattan distance method for place similar objects in one cluster is applied (Ciaschini et al., 2011). The cluster analysis uses three variables - crop production (USD/ha), use of fertilizers (MJ/ha), fuel consumption (MJ/ha) and use of pesticides (MJ/ha). All variables were averaged in the period 2002-2012. The agricultural area (hectares) includes arable land and permanent crops.

\section{RESULTS}

Data about crop output and energy inputs were downloaded from public FAOSTAT and EUROSTAT databases. The analysis covers the long-term period 2002-2012. So, the change in energy efficiency was calculated from 2002/03 to $2011 / 2012$. The period was divided into two halves. The second half represents major part of the "old" RDP (2007/08 - 2011/12). Since not all countries in the EU-28 are suitable to be included in the dataset, small countries (Malta, Luxembourg, Cyprus) and countries with incomplete time-series (Bulgaria) were excluded. Thus, the energy efficiency in the crop production was calculated in 24 countries. The analysis should reveal countries with highest and lowest improvement of the energy efficiency in time.

Table 1 and figure 1 inform about the results of the cluster analysis. There are only two clusters in the table because the third cluster was not homogeneous.

Table 1. Results of the cluster analysis

\begin{tabular}{|c|c|c|c|c|c|c|}
\hline Cluster & Country & $\begin{array}{c}\text { Silhouette } \\
\text { value }\end{array}$ & $\begin{array}{c}\text { Crop production } \\
(\mathrm{USD} / \mathrm{ha})\end{array}$ & $\begin{array}{c}\text { Fertilizers } \\
(\mathrm{MJ} / \mathrm{ha})\end{array}$ & $\begin{array}{c}\text { Transport fuels } \\
(\mathrm{MJ} / \mathrm{ha})\end{array}$ & $\begin{array}{c}\text { Pesticides } \\
(\mathrm{MJ} / \mathrm{ha})\end{array}$ \\
\hline \multirow{4}{*}{ Cluster 1 } & Belgium & 0.7760 & 2997.2 & 19007.5 & 21333.0 & 2191.1 \\
\cline { 2 - 7 } & Netherlands & 0.7751 & 3512.0 & 21407.6 & 17163.4 & 2097.2 \\
\cline { 2 - 7 } & Cluster average & 0.7755 & 3254.6 & 20207.6 & 19248.2 & 2144.1 \\
\hline \multirow{5}{*}{ Cluster 2 } & Latvia & 0.7556 & 370.5 & 3792.6 & 3119.7 & 196.9 \\
\cline { 2 - 7 } & Sweden & 0.7490 & 426.6 & 5558.7 & 3404.3 & 239.6 \\
\cline { 2 - 7 } & Lithuania & 0.7264 & 443.9 & 2772.8 & 812.5 & 239.9 \\
\cline { 2 - 7 } & Slovakia & 0.7180 & 612.9 & 5462.0 & 2038.8 & 298.4 \\
\cline { 2 - 7 } & Romania & 0.6973 & 630.0 & 2672.1 & 740.9 & 206.1 \\
\cline { 2 - 7 } & Estonia & 0.6905 & 300.9 & 3941.5 & 4863.0 & 214.4 \\
\cline { 2 - 7 } & Czech Republic & 0.6056 & 580.7 & 6207.5 & 4187.5 & 386.0 \\
\cline { 2 - 7 } & Hungary & 0.5123 & 808.8 & 5489.3 & 2099.8 & 501.0 \\
\cline { 2 - 7 } & (Finland) & $(0.4749)$ & $(331.5)$ & $(7505.3)$ & $(6679.0)$ & $(216.7)$ \\
\cline { 2 - 7 } & Cluster average & 0.6589 & 500.7 & 4822.4 & 3105.0 & 277.7 \\
\hline
\end{tabular}

Source: author

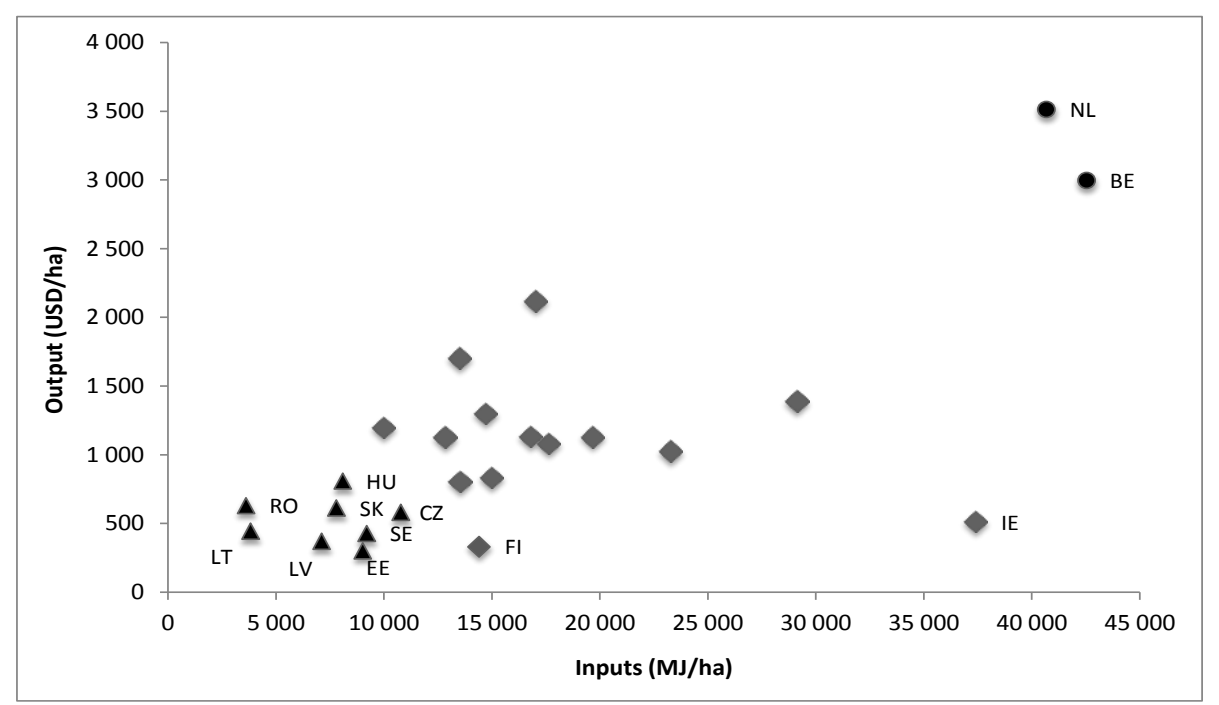

Source: author

Figure 1. Clusters by energy efficiency in the crop production (2002-2012)

In the EU, there are two distinct clusters of countries by the energy efficiency of the crop production. Cluster 1 contains Benelux countries with intensive farming which also requires high energy inputs per hectare. In the cluster 2 , 
there are countries from the Central Europe (Czech Republic, Slovakia, Hungary), all Baltic countries (Lithuania, Latvia, Estonia), Sweden and Romania. Silhouette value of Finland is below 0.5 which means that Finland does not statistically belongs to the cluster 2. Countries in the cluster 2 have quite low crop production and low energy inputs. It is obvious that clusters are formed by farming intensity and production conditions of each country.

There is also one country that seems to be extreme with high energy inputs and low crop production per hectare - Ireland. It has high use of fertilizers per hectare and low crop production per hectare. Ireland has specific structure of agricultural production. The most important sector of Irish agriculture is extensive sheep grazing. Wool is exported to other countries. Except meadows and pastures without any direct market production, Ireland mostly produces cereals - barley, wheat and oats.

Table 2 contains the results of progress in the energy efficiency in the EU. We also compare the first and the second half of the period, frontier shift and catch up. Countries are arranged by the Malmquist index (MI) in 2002/2003-2011/2012.

Table 2. Change in energy efficiency in the period 2002-2012

\begin{tabular}{|c|c|c|c|c|c|}
\hline Country & $\begin{array}{c}\text { Malmquist index } \\
(02 / 03-11 / 12)\end{array}$ & $\begin{array}{c}\text { Malmquist index } \\
(02 / 03-06 / 07)\end{array}$ & $\begin{array}{c}\text { MI (07/08-11/12) } \\
\text { "recent years" }\end{array}$ & $\begin{array}{c}\text { Catch Up } \\
(02 / 03-11 / 12)\end{array}$ & $\begin{array}{c}\text { Frontier shift } \\
(02 / 03-11 / 12)\end{array}$ \\
\hline United Kingdom & 1.1192 & 1.2029 & 1.0354 & 1.0375 & 1.0695 \\
\hline Portugal & 1.0960 & 1.0989 & 1.0931 & 1.0822 & 1.0258 \\
\hline Sweden & 1.0692 & 1.0642 & 1.0741 & 1.1151 & 0.9727 \\
\hline Greece & 1.0617 & 1.0432 & 1.0802 & 1.0008 & 1.0588 \\
\hline Romania & 1.0483 & 1.0407 & 1.0558 & 1.0000 & 1.0483 \\
\hline Austria & 1.0450 & 1.0875 & 1.0026 & 1.0427 & 1.0216 \\
\hline France & 1.0325 & 0.9606 & 1.1044 & 1.0679 & 1.0128 \\
\hline Belgium & 1.0292 & 1.0326 & 1.0258 & 1.0055 & 1.0420 \\
\hline Netherlands & 1.0268 & 1.0144 & 1.0392 & 1.0297 & 1.0154 \\
\hline Slovenia & 1.0133 & 1.0084 & 1.0182 & 1.0308 & 0.9861 \\
\hline Spain & 1.0133 & 0.9858 & 1.0408 & 1.0000 & 1.0133 \\
\hline Hungary & 1.0122 & 0.9772 & 1.0471 & 1.0403 & 0.9914 \\
\hline Finland & 1.0056 & 1.0261 & 0.9851 & 1.0643 & 0.9795 \\
\hline Ireland & 1.0031 & 0.9528 & 1.0534 & 1.0639 & 0.9518 \\
\hline Germany & 1.0014 & 0.9956 & 1.0072 & 1.0205 & 1.0016 \\
\hline Slovakia & 0.9995 & 0.9719 & 1.0271 & 1.0622 & 0.9440 \\
\hline Croatia & 0.9936 & 0.9405 & 1.0466 & 1.0345 & 0.9895 \\
\hline Czech Republic & 0.9917 & 0.9638 & 1.0197 & 0.9978 & 1.0107 \\
\hline Denmark & 0.9805 & 0.9646 & 0.9963 & 0.9851 & 1.0097 \\
\hline Italy & 0.9751 & 1.0114 & 0.9389 & 1.0000 & 0.9751 \\
\hline Estonia & 0.9673 & 0.9730 & 0.9617 & 1.0000 & 0.9673 \\
\hline Poland & 0.9607 & 0.9219 & 0.9995 & 0.9836 & 0.9896 \\
\hline Lithuania & 0.9554 & 0.9057 & 1.0051 & 1.0000 & 0.9554 \\
\hline Latvia & 0.9249 & 0.8492 & 1.0006 & 0.9880 & 0.9405 \\
\hline Sora & & & & & \\
\hline
\end{tabular}

Source: author

The Malmquist index shows that the United Kingdom, Portugal and Sweden experienced the most dynamic progress in energy efficiency in the period 2002-2012. The United Kingdom increased the energy efficiency by $11.9 \%$ each year on average. The most significant progress was in the first half of the period (2002/03-2006/07), i. e. by more than $20 \%$ annually. The frontier shift is higher than the catch up effects which means that there was a change in the efficient frontiers between the time periods rather than an improvement of country's efficiency with respect to the frontier in each period/year. So, the innovation effect was the main cause of the efficiency improvement.

The second place takes Portugal with $9.6 \%$ annual change in the energy efficiency. Portugal was improving the energy efficiency continuously with similar dynamic in both halves of the period $(9.89 \%$ in 2002/03-2006/07, 9.31\% in 2007/08-2011/12). The catch up effect was higher than the frontier effect. So, the country improved its energy efficiency with respect to the frontier.

A dynamic of change in the energy efficiency in Sweden was higher in the second half of the period $(7.41 \%$ annually). Sweden continuously improved the energy efficiency with respect to the frontier (catch up effect). On the contrary, the frontier effect decreased (0.9727).

On the opposite end of the scale, there are Baltic countries and Poland. Lithuania and Latvia worsened the energy efficiency in the first half of the period. In recent years, the decline stopped (MI = 1.0051 in Lithuania, MI $=1.0006$ in Latvia). It indicates that Lithuania and Latvia make efforts to be more energy efficient. In both countries, the catch up effect was greater than the frontier effect which accents a recovery of efficiency in agriculture. In Poland, the energy efficiency annually dropped by $4 \%$. The catch up effect and the frontier shift decreased. However, there was a clear effort to enhance the energy efficiency in recent years $(\mathrm{MI}=0.9995)$ against the previous period $(\mathrm{MI}=0.9219)$.

The energy efficiency in the Czech Republic and Slovakia decreased. In recent years, the energy efficiency has improved by $2.71 \%$ per year in Slovakia and by $1.97 \%$ per year in the Czech Republic. There could be an effect of investment subsidies from the RDP since 2007 as in Lithuania and Latvia. Slovakia improved the energy efficiency with respect to the frontier in each year. The frontier shift (0.9440) implies some problems with innovation effects agriculture. Alternatively, the Czech Republic had higher frontier shift than catch up effect. It indicates the significant innovation 
effects because there was a positive change in the efficient frontiers in the period 2002-2012. In the Visegrad Group, only Hungary experienced the positive improvement of the energy efficiency, particularly in recent years $(\mathrm{MI}=1.0471$ in 07/08-11/12). The catch up effect prevailed.

The Benelux countries had similar positive change in the energy efficiency. Belgium ranked 8th and the Netherlands ranked 9th place in the table 2. The Netherlands have improved the energy efficiency more in recent years unlike Belgium. However, the Benelux countries with highly intensive farming have been very successful in efficiency improvement for a long time.

The comparison of the two periods reveals that 17 of 24 countries have improved the change in the energy efficiency since 2007. The group of 17 countries includes the Visegrad Group, two Baltic countries (Latvia, Lithuania), 8 countries from the "old" EU-15 (Denmark, France, Germany, Greece, Ireland, the Netherlands, Spain, and Sweden), Romania, Slovenia and Croatia. The most significant positive change in energy efficiency was in Latvia, France, Croatia and Lithuania. Alternatively, 7 of 24 countries worsened the change in the energy efficiency between the two periods. The biggest deterioration was in the United Kingdom, Austria, Italy and Finland (followed by Estonia, Belgium and Portugal).

\section{CONCLUSION}

Energy efficiency is an important indicator of sustainability of agricultural processes. The aim of the paper was to evaluate the change of the energy efficiency of crop production in the EU. Cluster analysis and analysis of the efficiency change in the period 2002-2012 provided interesting results. First, energy efficiency depends on farming intensity and production conditions of each country. So, there are countries with intensive high-input farms in Benelux and less intensive low- and medium-input farms in the Central Europe, Baltics and Scandinavia. The Malmquist index identified the United Kingdom, Portugal and Sweden as countries with the most dynamic progress in the energy efficiency in the period 2002-2012. However, the United Kingdom experienced the largest decline of energy efficiency from 2002/03-2006/07 to 2007/08-2011/12. The Baltic countries and Poland ranked the bottom positions. Their energy efficiency dropped. However, Lithuania, Latvia and Poland increased the Malmquist index in recent years, partly as a consequence of effective investments in upgrading of agricultural technology and equipment from the RDP. Most countries with mean efficiency decline in the period 2002-2012 (7 of 9) improved Malmquist index in the second half of the period. Only Italy and Estonia, both with efficiency decline, have worsened the mean energy efficiency since 2007.

The energy efficiency at the farm-level or commodity-level should count not only with direct energy inputs in the form of fossil energy inputs but it should also consider energy in indirect inputs, like seeds, fertilizers, pesticides, manufactured feeds, buildings and machinery. The investment support from the "new" RDP should further improve the energy efficiency of agriculture in all EU countries. Thus, the energy efficiency as a priority of the Common Agricultural Policy should be continuously monitored and evaluated by analysts, researchers and policy makers.

Acknowledgement. The paper was supported by the Internal Grant Agency of the University of Economics, Prague, project "Financial reporting systems analysis and identification of the impact on the company's financial indicators", No. F3/34/2015.

\section{REFERENCES}

1. Alonso, A. M., Guzman, G. J. 2010. Comparison of the Efficiency and Use of Energy in Organic and Conventional Farming in Spanish Agricultural Systems. Journal of Sustainable Agriculture, Vol. 34, Iss. 3, pp. 312-338. http://dx.doi.org/10.1080/10440041003613362

2. Blancard, S., Martin, E. 2012. Energy Efficiency Measurement in Agriculture with Imprecise Energy Content Information. CESAER INRA - AGROSUP, Working Paper, 2012/6. Available at http://www2.dijon.inra.fr/cesaer/workingpapers/RePEc/ceo/wpaper/wp2012_6.pdf (accessed on 08/08/2015).

3. Caves, D. W, Christensen, L. R., Diewert, W. E. 1982. The Economic Theory of Index Numbers and the Measurement of Input, Output, and Productivity. Economica, Vol. 50, Iss. 6, pp. 1393-1414. http://dx.doi.org/10.2307/1913388

4. Celik, Y., Peker, K., Oguz, C. 2010. Comparative Analysis of Energy Efficiency in Organic and Conventional Farming Systems: A Case Study of Black Carrot (Daucus carota L.) Production in Turkey. Philippine Agricultural Scientist, Vol. 93, Iss. 2, pp. $224-231$.

5. Ciaschini, M., Pretaroli, R., Socci, C. 2011. Balance, Manhattan Norm and Euclidean Distance of Industrial Policies for the US. Structural Change and Economic Dynamics, Vol. 22, Iss. 3, pp. 204-226. http://dx.doi.org/10.1016/j.strueco.2011.03.002

6. Cooper, W. W., Seiford, W. L., Tone, K. 2006. Introduction to Data Envelopment Analysis and Its Uses, Springer, New York.

7. Curtiss, J., Jelínek, L. 2015. Measuring Energy Efficiency and Shadow Costs of Energy Saving in Agriculture: Application to Wheat Production. Book of abstracts of the Joint International Scientific Conference "Agrarian Perspectives XXIV. - Global Agribusiness and the Rural Economy", Czech University of Life Sciences, Prague, Austrian Society of Agricultural Economics, pp. 17-18. Available at file:///C:/Users/spicka/Downloads/ap_sbornik_electronic\%20(1).pdf (accessed on 16/09/2015).

8. Hoang, V. N., Prasada Rao, D. S. 2010. Measuring and Decomposing Sustainable Performance in Agricultural Production: A Cumulative Exergy. Ecological Economics, Vol. 69, Iss. 9, pp. 1765-1776. http://dx.doi.org/10.1016/j.ecolecon.2010.04.014

9. Houshyar, E., Sheikh Davoodi, M. J. and Nassiri, S. M. 2010. Energy Performance for Wheat Production Using Data Envelopment Analysis (DEA) Technique. Journal of Agricultural Technology, Vol. 6, Iss. 4, pp. 663-672.

10. Hu, J. L., Wang, S. C. 2006. Total-factor Energy Efficiency of Regions in China. Energy Policy, Vol. 34, Iss. 17, pp. 3206-3217. http://dx.doi.org/10.1016/j.enpol.2005.06.015 
11. European Union. 2013. Article 5 (5b), Regulation (EU) No 1305/2013 of the European Parliament and of the Council of 17 December 2013 on Support For Rural Development by the European Agricultural Fund for Rural Development (EAFRD) and Repealing Council Regulation (EC) No 1698/2005.

12. Jelínek, L., Curtiss, J., Humpál, J., Medonos, T., Špička, J., Vilhelm, V. 2010. Economic system of farm efficiency evaluation respecting principles of sustainable natural resource management (in Czech), $1^{\text {st }}$ ed., Institute of Agricultural Economics and Information, Prague.

13. Kaufman, L., Rousseeuw, P. J. 1990. Finding Groups in Data: An Introduction to Cluster Analysis, Wiley, New York. http://dx.doi.org/10.1002/9780470316801

14. Kueters, J., Lammel, J. 1999. Investigations of the Energy Efficiency of the Production of Winter Wheat and Sugar Beet in Europe. European Journal of Agronomy, Vol. 11, Iss. 1, pp. 35-43. http://dx.doi.org/10.1016/S1161-0301(99)00015-5

15. Meul, M., Nevens, F., Reheul, D., Hofman, G. 2007. Energy Use Efficiency of Specialised Dairy, Arable and Pig Farms in Flanders. Agriculture Ecosystems \& Environment, Vol. 119, Iss. 1-2, pp. 135-144.

16. Nassiri, S. M., Singh, S. 2010. Energy Efficiency for Wheat Production Using Data Envelopment Analysis (DEA) Technique. Applied Energy, Vol. 6, Iss. 7-8, pp. 1320-1325.

17. Patterson, M. G. 1996. What is Energy Efficiency? Concepts, Indicators and Methodological Issues. Energy Policy, Vol. 24, Iss. 5, pp. 377-390. http://dx.doi.org/10.1016/0301-4215(96)00017-1

18. Risoud, B. 2000. Energy Efficiency of Various French Farming Systems: Questions to Sustainability. Proceedings of the International Conference "Sustainable Energy: New Challenges for Agriculture and Implications for Land Use", Wageningen University, Netherlands, May 18-20, 2000.

19. Smith, L. G., Williams, A. G., Pearce, B. D. 2015. The Energy Efficiency of Organic Agriculture: A Review. Renewable Agriculture and Food Systems, Vol. 30, Iss. 3, pp. 280-301. http://dx.doi.org/10.1017/S1742170513000471

20. Uzal, S. 2013. Comparison of the Energy Efficiency of Dairy Production Farms Using Different Housing Systems. Environmental Progress \& Sustainable Energy, Vol. 32, Iss. 4, pp. 1202-1208. http://dx.doi.org/10.1002/ep.11727

21. Vlontzos, G., Niavis, S., Manos, B. 2014. A DEA Approach for Estimating the Agricultural Energy and Environmental Efficiency of EU Countries. Renewable \& Sustainable Energy Reviews, Vol. 40, pp. 91-96. http://dx.doi.org/10.1016/j.rser.2014.07.153 